\title{
The story turn in tourism: forces and futures
}

\section{Gianna Moscardo}

Gianna Moscardo is based at the College of Business, Law and Governance, James Cook University, Townsville, Australia.
Received 8 November 2019 Revised 4 May 2020 Accepted 4 May 2020

(C) Gianna Moscardo. Published in Journal of Tourism Futures. Published by Emerald

Publishing Limited. This article is published under the Creative Commons Attribution (CC BY 4.0) license. Anyone may reproduce, distribute, translate and create derivative works of this article (for both commercial and non-commercial purposes), subject to full attribution to the original publication and authors. The full terms of this license may be seen at http://creativecommons. org/licences/by/4.0/legalcode

\begin{abstract}
Purpose - The purpose of this paper is to highlight the rise of stories in tourism practice, identify the forces that are supporting and directing this story turn and argue for tourism researchers to pay greater attention to this new development.

Design/methodology/approach - This paper is based on a general review of academic and professional literature on marketing practice and experience design in tourism and an audit of destination marketing materials using story or story telling in their campaigns.

Findings - This paper identifies three forces supporting a story turn in tourism: building on the experiential approach to tourism; the rise of mobile social media, user generated content and gamification; and the Asian Wave in tourism.

Originality/value - This paper identifies a story turn in current tourism practice and reviews the increasing awareness of the value of stories in psychology, sociology and anthropology research, to suggest how this story turn may influence the nature of both tourism practice and research in the future.
\end{abstract}

Keywords Stories, Storytelling, Experience design, Tourism futures, Story turn

Paper type Trends paper

\section{Introduction}

This paper argues that the use of "story" in tourism practice has grown considerably in the past five years, and this reflects a growing recognition that stories are a key driver of, and influence on, tourists' cognitions and behaviors. It specifically identifies three forces supporting this story turn: the further development of the experience economy, the rise of digital mobile technologies, and the changing profiles of international tourists. This paper then notes the existence of a "story turn" in research areas outside tourism academia including anthropology (Dunn, 2017), sociology (Polletta et al., 2011), psychology (Popova, 2015) and marketing (Woodside, 2010). It concludes by arguing that to date tourism research has paid little attention to this research and thus may be falling behind tourism practice and other social science disciplines.

Before describing these forces and implications for tourism futures, it is important to define what a story is and distinguish it from a narrative; to briefly describe the nature of the evidence presented in this trends paper and to give an overview the current state of stories in tourism practice. In terms of definition, Poletta et al. (2011) define narratives as a broad category of descriptions of events told in order of occurrence. Moscardo (2018) goes on to argue that stories are a very specific type of narrative that are designed explicitly to entertain, engage emotions and change their audience and that a story must include descriptions not just of a set of causal chains of events but also descriptions of characters, how they respond to these events and the consequences of these reactions. While the term narrative turn has been used to describe a shift in social sciences to studying the lived experience of individuals expressed in their own words (Clandinin, 2016), the story turn is 
about the explicit recognition of the centrality of this particular type of narrative to human experience (Gottschall, 2012).

This paper is based on two main approaches to evidence gathering. The first was an audit of the explicit use of both the word stories in tourism practice and evidence of stories embedded in activities offered to tourists in a range of settings. This audit was done with a series of internet searches in English using various combinations of "story, storytelling, tourist, tourism, destination marketing, and experience." This search typically generated articles and advertisements for various destinations and tourism businesses, as well as news items about successful tourism advertising campaigns and tourist experiences. This internet search also included blogs and resources offered by destination marketing and management agencies in both the public and private sector. This audit provided an overview of the current usage of "story" in tourism practice. The second source of evidence was an extensive and comprehensive literature review using multiple academic search engines looking for story, stories and storytelling in tourism research and the wider social science literatures. Space limitations preclude more details, but this review is based on more than 5,300 referred academic papers.

\section{Stories in current tourism practice}

Stories have always been part of tourism, most clearly in guided tours and attractions built around either stories in popular culture (such as Disneyland and tours to places associated with novels, films and television), or presentations of destination history and culture. These existing examples are almost exclusively about telling the stories of the destination to tourists. The audit of stories in current tourism practice reveals however the rising explicit use of tourists' stories in tourism destination promotion is clear. From Abu Dhabi's "Your Extraordinary Story" campaign, and Korea's invitation to "Let your story begin" through to Poland's "Move your imagination - come and find your story." There is also evidence of tourists being encouraged to create their own stories in the design of onsite tourist experience opportunities and Hansen et al. (2012) and Mathisen (2013) provide examples of these story-based experience opportunities. The former adoption of stories in destination promotions is clearly linked to official destination marketing agencies, while the latter is more closely tied to innovative tourism producers.

\section{Force 1: building on the experiential turn}

Yeoman and McMahon-Beattie (2019) in their review of trends associated with the concept of the experience economy argued that experiences are already well embedded as a core focus for tourists and tourism providers. They further noted that "the desire to collect 'stories' underpins [so] many of our consumption choices" (p. 114). Moscardo's (2010) review of the features that have been consistently associated with positive experiences also concluded that stories are central concepts in tourist experiences. As people embrace the experiential turn in travel, stories are becoming more widely recognized as important structures for the design of experience opportunities (Moscardo, 2017, 2018).

\section{Force 2: mobile social media, user generated content and gamification}

IAs previously noted some onsite tourism experiences have always been based on stories of the destination told to tourists. The rise of location-based and digital mobile technologies now allow, however, for more varied, active and creative opportunities for visitors not just to hear, see or re-enact a destination story but also to create their own personal and increasingly imaginative story with the destination as the setting (Hansen et al., 2012; Mathisen, 2013). Many of the interactive mobile apps being designed for tourism are either actual games or include elements of games. This trend toward gamification in tourism is being paid increasing attention by researchers (Skinner et al., 2018; Xu et al., 2014). 
The importance of building digital games around strong stories is a common theme in the wider literature on successful game design (Lebowitz and Klug, 2011).

Another important element of the impact of digital apps and mobile social media on tourism has been the rise of user-generated content (UGC) shared online as an influence on tourist decision-making (Zeng and Gerritsen, 2014). Of particular interest to the present discussion is the growing research evidence that social media interactions are clearly built around stories (Page, 2012) and that UGC presented as a story attracts more audience attention (Volo, 2010) and enhances destination images and intentions to visit (Tussyadiah et al., 2011).

\section{Force 3: Asian wave in tourism}

There is no doubt that one of the most obvious trends in tourism in the past decade has been the rise in international tourists coming from mainland China and India with impressive growth in outbound tourism from countries such as Thailand and Malaysia (UNWTO, 2018). To date, most attention has been paid to China. In addition to widespread and intensive use of social media (Zhang and Pentina, 2012), Chinese tourists are also noteworthy in their active use of destination stories to both make decisions about where to go and what to do in destinations, and to make personal connections to the places they are visiting (Cui et al., 2017). Domestic tourism providers in China often structure experience opportunities around stories from history, poetry, literature and folktales (Ballantyne et al., 2014). While research describing Indian international tourists is rare, there is some evidence that this group is also likely to be responsive to destination stories (Sinha and Sharma, 2009).

\section{Wider context: story turn in social sciences}

In part, the rise of the use of stories in destination promotion reflects the use of stories in the wider world of marketing with widespread use of brand stories, business stories, producer stories and stories linked to all sorts of products. This adoption of stories in marketing reflects the increasing attention being paid by consumer behavior and marketing researchers to stories as a tool to attract consumers (Woodside, 2010). In turn, this reflects the centrality of stories to psychology (Popova, 2015), sociology (Polletta et al., 2011) and anthropology (Dunn, 2017). As Gottschall (2012) notes, neuroscientists have demonstrated that stories are literally hardwired into human brains and so influence the way we organize, make sense, store and remember information, how we determine, maintain and express individual and social identity and how we learn and communicate (Pearce and Moscardo, 2019). In addition to the tourism research into UGC, there is an increasing interest in stories as a guide to experience design (Moscardo, 2010, 2017, 2018; Woodside, 2010).

\section{Implications for tourism practice futures}

Figure 1 provides a simple model of the three main components of a tourist system: the tourism providers, the tourists and the destinations and communities that host tourism. In the very centre where all the three of these components intersect are tourist experiences which also extend into the connection between tourists and destination communities. This extension recognizes that not all tourist experiences occur within the control of tourism providers. The connection between tourism providers and tourists is where destination promotion exists, and the intersection between tourism providers and destination communities is the realm of destination planning. Currently stories are in wide use in destination promotion, and they are being used increasingly in the design of experience opportunities in the very central intersection of all three components, with some tentative developments in linking destination residents and their stories directly to tourists. 


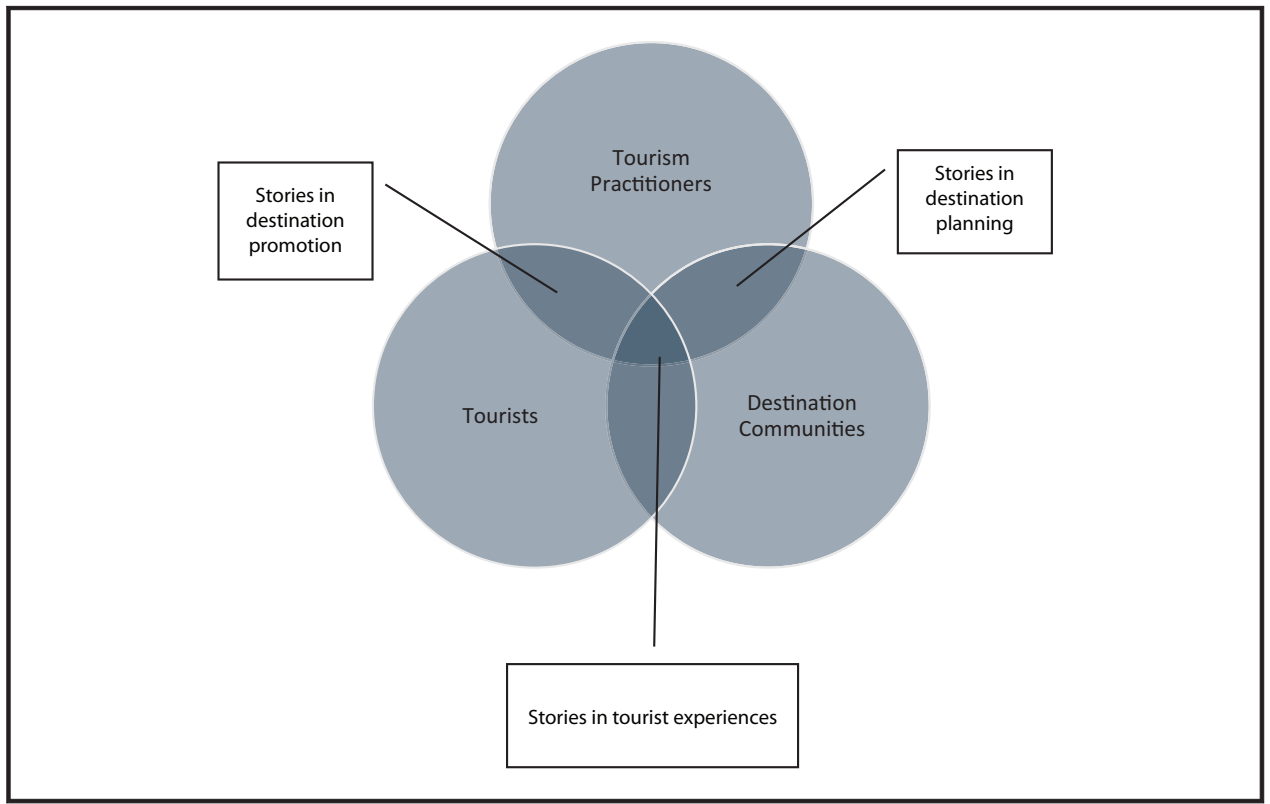

The first prediction for tourism practice futures is that there will be increasing, and increasingly sophisticated, use of stories in destination promotion and experience opportunity design. For experience opportunity design, it is likely that there will be both a move to increasing tourist engagement and interaction with destination stories and a move to focusing experience opportunities not just on destination stories but on tourists creating their own stories. For destination promotion, it is likely that this will not only involve what has been called transmedia storytelling using a variety of communication channels (Pearce and Moscardo, 2019) but also support the development of destination story worlds connected with themes that highlight the destination's distinctiveness, that are appealing to tourism and that are acceptable to destination communities.

Looking to the future, this model suggests a number of other predictions about the story turn in tourism practice. The recognition of the need to build coherent story worlds for destination marketing and promotion highlights the issue of ensuring that destination communities are more extensively and intensively involved in destination planning. At a very specific level, futures scenarios used in planning can be, and sometimes are, presented as stories, and stories will become important elements of planning activities. At a broad level, destination planning is about creating a story of tourism that links all the stakeholders in a positive way. A more aspirational tourism future then is one where the story of tourism is more about supporting sustainability in destination communities and using tourism as a way to tell stories of sustainability that tourists can take and apply to their lives beyond travel.

\section{Implications for tourism research futures}

This "story turn" represents both opportunities and challenges for tourism research. In terms of opportunities, the explicit use of stories in various aspects of tourism has not yet been systematically analyzed or evaluated offering a number of research opportunities with the potential to both guide actual practice and enhance understanding of tourists and tourism. In terms of challenges, the review found that while a number of tourism researchers use the word story in their papers, they almost never provided a definition of a story, never referred 
to the extensive literature on stories available in the core social science disciplines and other applied social sciences area and in many cases, provided no evidence that they had studied stories at all. Thus tourism researchers will have to significantly improve their attention to these scholarly basics if they are to avoid pursuing futile pathways or reinventing wheels that have already been turned into sophisticated vehicles in other academic areas.

\section{References}

Ballantyne, R., Hughes, K., Ding, P. and Liu, D. (2014), "Chinese and international visitor perceptions of interpretation at Beijing built heritage sites", Journal of Sustainable Tourism, Vol. 22 No. 5, pp. 705-725.

Clandinin, D. (2016), Engaging in Narrative Inquiry, Routledge, Abingdon.

Cui, Q., Liao, X. and Xu, H. (2017), "Tourist experience of nature in contemporary China", Journal of Tourism and Cultural Change, Vol. 15 No. 3, pp. 248-264.

Dunn, C. (2017), "Personal narratives and self-transformation in postindustrial societies", Annual Review of Anthropology, Vol. 46 No. 1, pp. 65-80.

Gottschall, J. (2012), The Storytelling Animal, Houghton Mifflin Harcourt, New York, NY.

Hansen, F., Kortbek, K. and Grønbæk, K. (2012), "Mobile urban drama”, New Review of Hypermedia and Multimedia, Vol. 18 Nos 1/2, pp. 63-89.

Lebowitz, J. and Klug, C. (2011), Interactive Storytelling for Video Games, Elsevier, Amsterdam.

Mathisen, L. (2013), "Staging natural environments", Advances in Hospitality and Leisure, Vol. 9, pp. 163-183.

Moscardo, G. (2010), "The shaping of tourist experience", in Morgan, M., Lugosi, P. and Ritchie, J. (Eds), The Tourism and Leisure Experience, Channel View, Bristol, pp. 43-58.

Moscardo, G. (2017), "Stories as a tourist experience design tool”, in Fesenmaier, D. and Xiang, Z. (Eds), Design Science in Tourism, Springer International Publishing, Basel, pp. 97-124.

Moscardo, G. (2018), "Tourist experience design", in Cai, L. and Alaedini, P. (Eds), Quality Services and Experiences in Hospitality and Tourism, Emerald, Bingley, pp. 93-108.

Page, R. (2012), Stories and Social Media, Routledge, New York, NY.

Pearce, J. and Moscardo, G. (2019), "The role of stories in travel posts to social media", in Mansson, M., Buchmann, A., Cassinger, C. and Eskilsson, L. (Eds), Routledge Companion to Media and Tourism, Routledge, London.

Polletta, F., Chen, P., Gardner, B. and Motes, A. (2011), "The sociology of storytelling", Annual Review of Sociology, Vol. 37 No. 1, pp. 109-130.

Popova, Y. (2015), Stories, Meaning, and Experience, Routledge, Abingdon.

Sinha, A. and Sharma, Y. (2009), "Urban design as a frame for site readings of heritage landscapes", Journal of Urban Design, Vol. 14 No. 2, pp. 203-221.

Skinner, H., Sarpong, D. and White, G. (2018), "Meeting the needs of the millennials and generation Z", Journal of Tourism Futures, Vol. 4 No. 1, pp. 93-104.

Tussyadiah, I., Park, S. and Fesenmaier, D. (2011), "Assessing the effectiveness of consumer narratives for destination marketing", Journal of Hospitality \& Tourism Research, Vol. 35 No. 1, pp. 64-78.

UNWTO (2018), "Tourism highlights 2018 edition", available at: www.e-unwto.org/doi/pdf/10.18111/ 9789284419876 (accessed 1 October 2018).

Volo, S. (2010), "Bloggers' reported tourist experiences", Journal of Vacation Marketing, Vol. 16 No. 4 , pp. 297-311.

Woodside, A. (2010), "Brand-consumer storytelling theory and research", Psychology and Marketing, Vol. 27 No. 6, pp. 531-540. 
Xu, F., Weber, J. and Buhalis, D. (2014), "Gamification in tourism", in Xiang, Z. and Tussyadiah, I. (Eds), Information and Communication Technologies in Tourism 2014, Springer, Cham, pp. 525-537.

Yeoman, I. and McMahon-Beattie, U. (2019), "The experience economy", Journal of Tourism Futures, pp. 114-119.

Zeng, B. and Gerritsen, R. (2014), "What do we know about social media in tourism?", Tourism Management Perspectives, Vol. 10, pp. 27-36.

Zhang, L. and Pentina, I. (2012), "Motivations and usage patterns of weibo", Cyberpsychology, Behavior \& Social Networking, Vol. 15 No. 6, pp. 312-317.

\section{Corresponding author}

Gianna Moscardo can be contacted at: gianna.moscardo@jcu.edu.au

For instructions on how to order reprints of this article, please visit our website: www.emeraldgrouppublishing.com/licensing/reprints.htm

Or contact us for further details: permissions@emeraldinsight.com 